\title{
Research of Related Issues of the Guarantee of Farmers' Legal Rights and Interests in Land Transfer
}

\author{
Yubing Yang ${ }^{1, \text { a }}$, Zhanping $\mathrm{Li}^{1, \mathrm{~b}}$, and Le Wang ${ }^{1, \mathrm{c}}$ \\ ${ }^{1}$ School of Ningbo Dahongying University, Ningbo 315175, China \\ a79632032@qq.com, byybljf@163.com, 540318133@qq.com
}

Keywords: land transfer; farmers’ rights and interests; guarantee measures

\begin{abstract}
Land is the important resource and material foundation for the construction of new villages and new-type urbanization. Whether the land transfer mechanism is complete and smooth and whether it can satisfy the social and economic development demands directly influences the healthy development of domestic social economy. However, influenced by various factors, the phenomenon that the land transfer violates farmers' legal rights and interests occurs from time to time, which not only causes the terrible social influence, but also enlarges the obstacle of land transfer, which is unfavorable for the comprehensive implementation of the new-type urbanization construction. Based on this, this paper analyzes the concept, role and significance of land transfer, discusses about the violation of farmers' rights and interests in land transfer and the reasons. It also proposes the guarantee measures of farmers' legal rights and interests in land transfer, hoping this paper can provide some references for the domestic land transfer work.
\end{abstract}

\section{Introduction}

Under the new situation, to speed up the rural land transfer and help with the structural adjustment of agricultural industry is the important system orientation of domestic land reform and plays an important role in solving the issue of "agriculture, farmer and rural area". however, the violation of farmers' rights and interests in land transfer goes against the original intention of central formulation of land transfer policy, hurts farmers' initiative of participating in land transfer, triggers many land disputes and causes severe obstacle to the sustainable development of the rural social economy. Therefore, to strengthen the protection research of farmers' legal rights and interests in land transfer is of great realistic meaning.

\section{Concept of Land Transfer}

Land transfer is a kind of economic behavior in which farmers transfer the collective land they contract to other farmers or economic organizations through subcontracting, rental, exchange, transfer and entrusted management. The nature of land ownership after transfer is not changed. The original farmers hold the land contracting right and continue to fulfill the contracting agreement to the village (except for the transfer form). Therefore, the land transfer is actually the transposition of the management subject. The transfer-in can enjoy the usufruct of land, but cannot gain the complete disposition.

\section{Role and Significance of Land Transfer}

\subsection{Improve the Land Use Ratio.}

Intensive management is the important orientation of agricultural economic development under the system of market economy. Through the mode of land transfer, it breaks the small-scale economic pattern of the previous family decentralized operation and promotes the agricultural production to 
turn from the coarse type to intensive type, which facilitates the planting households to carry out the concentrated and continuous plantation. The machinery farming mode is adopted, so as to greatly improve the land use ratio. In addition, the transferred land can also be regarded as the agricultural pilot base or various demonstration gardens to cultivate the new agricultural varieties and explore the new agricultural technologies, effective improve the agricultural science technology contents and promote the improvement of agricultural output and benefits.

\subsection{Promote the Land Scaled Management.}

Land transfer is the necessary product that the agricultural economy develops to a certain degree. It is the basic system guarantee of realizing intensive, scaled and modernized agriculture. On the one hand, after the farmers transfer land, they can choose the free labor or devote themselves to the non-agricultural industry, so as to effective promote the prosperity of the second and the third industry of villages. On the other hand, the land transfer-in can arrange and adjust the land farming structure, expand the agricultural production scale, greatly improve the labor production rate, so as to reach the purpose of scaled management and agricultural increment.

\subsection{Satisfy the Urban and Rural Overall Development Demands.}

Land is the basic element of agricultural production and is the indispensable important asset for the farmers to maintain the livelihood. Land transfer helps the effective flow and reallocation of the labor force, capital and technology, which invisibly promotes the circulation of urban and rural resources in the market economy, so as to fully exert the benefit coordination mechanism of the market, eliminate the structural contradiction in the urban and rural development and realize the win-win of the overall coordination development of the urban and rural economy.

\section{Violation Issue of Farmers’ Rights and Interests in Land Transfer}

\subsection{Violation of Land's Random Adjustment and Withdrawal of Farmers' Right to Contracted Management.}

The current land policy stipulates that the contracting time limit of rural land is 30 years, but the grassroots governments and common farmers have different understandings of this policy. Farmers hold that the "remaining unchanged in 30 years" proposed in the policy targets at a certain farmer; however, the town governments hold that it targets at the plot" within 30 years of land contracting, the farmers contracting the plot can make flexible adjustments and change, so that the grassroots government randomly adjusts and reclaim farmers' contracted land. Although the property law in our country stipulates that farmers' contracted land cannot be randomly reclaimed or adjusted within the land contracting period, unless otherwise stipulated by the law. However, adjustment of contracted land often occurs in real life. Meanwhile, the increasing land expropriation demand of the local government also unavoidably leads to the frequent adjustment of rural contracted land, which is bound to violate farmers' right to contracted management of land. In addition, in order to realize the scaled management objective, the contract-issuing party randomly destroys the produces planted by farmers, compel the farmers to purchase designated grain seeds and conduct unified plantation and management, thus severely violating farmers' autonomous right of production and management.

\subsection{Violation of Unreasonable Land Acquisition Compensation of Farmers' Compensation Right.}

At present, there has not been a set of scientific and mature land acquisition compensation system in our country. When formulating the standards of land acquisition compensation, some local governments do not fully consider the local economic development levels, nor ask the third party evaluation organizations to make the fair and reasonable evaluation; the administrative organs unilaterally determine the compensation standards. Some local governments even gain the management and use right of land through compulsory expropriation and only give a little land 
acquisition compensation to farmers. These expenses are far lower than the actual asset value of the expropriated plots and cannot guarantee the living demands of farmers who lose land. In addition, there is no concrete stipulation about the land acquisition compensation standards in the current laws. The phenomenon of less approval and more expropriation, more occupation and less compensation exists in practice. No compensation is even given in some cases, thus severely violating farmers' legal rights and interests.

\subsection{Violation of Land Use Change of Farmers’ Legal Rights and Interests.}

Domestic land contracting law stipulates that the land transfer cannot change the agricultural use of land. However, out of lack of reasonable planing, some land transfer-in parties arbitrarily use the land for other purposes without the consent of the transfer-out parties, which not only violates related stipulations of the land law, but also leads severe destruction to land quality. When the contract expires, the farmers have to spend a lot of manpower and materials to renovate the land, thus greatly increasing the plantation cost of land. For example, some enterprises randomly build factories and pave roads on the leased circulated land, thus ultimately changing the land use. Although these enterprises pay a sum to the farmers regularly every year to compensate, yet many of them choose to escape in the case of mismanagement, which cannot fully cash the compensation promises and leads great harm to farmers' rights and interests.

\subsection{Violation of Disorderly Land Transfer of Farmers' Land Rights and Interests.}

In the current stage, the intermediary organizations in rural land transfer transaction are lacking. There is no according supervision organization that supervises and manages the land transfer process, thus leading to many nonstandard operation behaviors in various sections of land transfer. Although the country sets the related functional departments such as Land and Resources Bureau, which are responsible for the land planning, protection and approval, yet these organizations do not own the supervision and management right of land transfer, thus leading to the frequent violation of farmers' rights and interests in land transfer. In addition, the current land transfer procedures are not standard and complete, the farmers' cultural levels are low, so that farmers have the condition of random operation and disorder in the process of land transfer. Many farmers do not even sign the written contract and only have the oral agreement with the transfer-in parties. Once both parties have disputes, the rights and interests of farmers are difficult to be guaranteed.

\subsection{Violation of Excessive Intervention of Farmers’ Economic Benefits.}

In the land right relationship, the village committee has both the administrative and economic function, which is at the relatively strong status. However, farmers are at the weak status. If the village committee cannot sincerely consider for farmers' benefits, in addition to the administrative intervention of local governments, it is easy for them to make the land arrangement against farmers' will and destroy the normal order of the land transfer market. For example, in the contracting process of land, some grassroots cadres do not consider about the actual feelings of farmers and local conditions. With the excuse of the agricultural industry structure adjustment and scaled management, they force to promote the land transfer, which not only violates farmers' autonomous decision-making right, but also occupies the land benefits which should belong to farmers.

\section{Guarantee Measures of Farmers' Legal Rights and Interests in Land Transfer}

\subsection{Respect and Maintain Farmers' Right to Contracted Management of Land}

Rural Land Contracting Law of People's Republic of China gives clear statement of the rights and obligations of the responsible party, contract-issuing party and contracting party. It points out that the right to contracted management of land is a basic land right of farmers. Therefore, in order to protect the legal rights and interests of farmers in land transfer, the key is to implement the legal stipulation, respect and maintain farmers' right to contracted management of land. Concretely speaking, the 
grassroots governments have to strictly adhere to the land transfer principle of "legal, voluntary and paid”. Forbid compulsorily expropriating farmers' land in the name of the public benefit. If it is indeed out of the demand for new village construction, the superior departments must approve it and give reasonable payment to the farmers of land acquisition. Meanwhile, guarantee that any organization or individual cannot deprive of nor restrict farmers' rights and interests of contracting land. Within the land contracting period, the contracting party legally enjoys the right of land use, benefit and management right circulation. The contract-issuing party shall not adjust or reclaim the land with any reason.

\subsection{Strengthen the Construction of Related Systems of Land Transfer.}

First of all, the departments have to strengthen the standard management of land transfer contract, unify the contract format in strict accordance with the contract paradigm formulated by the local government and make clear the issues such as use of land transfer, circulation time limit, payment of circulation sum, rights and obligations of both parties, responsibility for breach of contract, dispute solutions. When the contract is changed, take the initiative to strengthen the business guidance of farmer and help farmers deal with related change work. Second, the land transfer management department should set up the management system of special staff for special responsibilities, actively organize the employees to collect, arrange and check the land materials, mainly censor whether the circulated land has the unsettled disputes or solutions, whether related contract parties own the according abilities and qualifications, whether the contracting contract has loopholes; prevent the land or employees that do not keep in line with the stipulations from entering the circulation market, so as to avoid the unnecessary contract disputes. Third, guarantee the equal dialogue right of related parties of land transfer. In particular, ensure the farmers at the disadvantageous status can equally conduct the negotiations of land transfer matters. Finally, formulate the dispute mediation mechanism of land transfer, set up the three-level land transfer service network that covers the city, the town and the village, provide related legal policy consultation and information inquiry service, help farmers mediate about the disputes and contradictions that appear in the process of land transfer, guarantee the smooth appeal channels for farmers, guarantee farmers' legal rights and interests in land transfer.

\subsection{Strengthen Legal Knowledge Propaganda of Farmers.}

On the one hand, the grassroots government needs to strengthen the legal knowledge propaganda of farmers, organize the special staff to solve the latest policies and regulations of land transfer for farmers, keep improving the legal awareness of farmers, strengthen farmers' ability of maintaining their legal rights and interests through the legal weapons and eliminate farmers' worries about land transfer. On the other hand, vigorously publicize the role and significance of land transfer to farmers. Use the traditional media approaches such as television, newspaper, leaflet and broadcasting, as well as the new media such as Weibo and WeChat for widespread publicity, form the all-round and stereo publicity pattern, make farmers realize the huge bonus of land transfer an further change farmers' conservative and rigescent land concepts, actively participate in the trend of land transfer. Besides, strengthen the training and guidance for grassroots cadres, regularly organize them to learn from the national land transfer policies, cultivate their awareness and concept of knowing about the law and abiding by law, improve their ability of administration according to law. In dealing with the related matters of land transfer, strictly handle affairs according to the laws and stipulation, get rid of the simple and rude administrative intervention act, truly lead the village members to do the work of land transfer.

\subsection{Set up and Complete the Rural Social Guarantee System.}

Land is not only the important source of farmers' production and life materials and the carrier of rural society guarantee, set up and complete the land transfer guarantee mechanism, perfect the rural social guarantee system, from the new pattern of rural development of "losing land but not losing jobs, nor losing benefits”, which is of great importance in guaranteeing farmers' benefits. Therefore, firstly, strengthen the rural reform process, take the opportunity of agricultural industrialization, rural 
urbanization, farmer citizen and equalization of basic public services, vigorously promote the census register system, land transfer system, rural labor force education and employment system. The farmers in land circulation should be firstly included the social guarantee scope and enjoy the same preferential treatment with the laid-off workers in the towns in terms of reemployment, training of post transfer and employment. For farmers that enter the towns, give them the policy preferential in terms of children education and economically affordable houses.

\subsection{Guarantee Farmers’ Principal Status in Land Transfer.}

In the past, farmers were not familiar with the policy and regulation of land transfer and with the value-added potential of land, many local governments pushed land transfer with the compulsory means and did not care about farmers' benefits and appeals, so that a large number of farmers failed to gain the satisfying compensation. In the process of land transfer, there was the vivid contrast between the high value of land and the low circulation benefit of farmers, thus leading to the frequent conflicts of both parties of circulation, which not only harmed farmers' legal rights and interests, but also influenced the further implementation of land transfer. Therefore, farmers' right to say in land transfer should be fully guaranteed. Formulate the land transfer policies on the basis of "returning rights to farmers" and the legal, voluntary and paid principle, provide multiple different circulation forms for farmers to choose freely, guarantee farmers to gain the due land value-added benefits in land transfer and fully guarantee farmer's dominant status in land transfer and their legal rights and interests.

\section{Summary}

Land transfer affects the whole body, which has the important influence on the harmonious and stable development of the rural society and the entire country. At present, the domestic land transfer system is not perfect and the violation of farmers' rights and interests still often occurs. Therefore, start from the power clarification, system construction, legal propaganda and social guarantee, keep completing the land transfer working mechanism, optimize the market order of land transfer, improve farmers' protection ability of their rights and interests in land transfer, create the fair, efficient, standard and orderly new pattern of land transfer, fully play the important role of land transfer in the rural economic construction.

\section{Acknowledgements}

Ningbo soft science research project funding project (No. 2015A10073), Ningbo technology and enriching project (No. 2016C10019).

\section{References}

[1] Yu Jianrong. Prevention of Farmers’ Benefit Harm in Land Transfer. People's Tribune, 13(2016) 72-74.

[2] Guo Dong, Di Minxue. Play the Role of Government in the Rural Land Transfer. Theoretical Exploration, 3(2017)122-126.

[3] Lang Dapeng. Thoughts of the Issue of Farmers' Pension Guarantee under the System of Rural Land Transfer. Agricultural Economy, 9(2016) 78-80.

[4] Lu Zhizeng. Research of the Protection of Farmers' Rights and Interests in Rural Land Transfer-Taking Longzhou County in Guangxi as the Example. Guizhou Ethnic Studies, 36(2016)40-43.

[5] Zhang Ke. On Legal Protection of Farmer' Rights and Interests in Rural Land Transfer. Agricultural Economy, 1(2015) 13-15. 
[6] Zhang Shoufu, Zhang Shaoting. Thinking of Strategy of Land Contracting Right System Reform under “Allocation of Three Rights”. Issues in Agricultural Economy, 2(2017)9-15.

[7] Li Xiaohong, Huang Jin. Property Right Logic of Farmers’ Loss of Land Property Right under the Farm Land System of Allocation of Three Rights. Journal of Guangxi University For Nationalities: Social Science Edition, 6(2016)163-167.

[8] Huang Zengfu. Research of the Land Benefited Status Change of Land Transfer and Elder Farmers. Social Sciences in Ningxia, 5(2015)74-80.

[9] Shen Jianxin. Research of Rural Land Transfer Reform in Fujian Province Based on Farmers' Rights and Interests guarantee. Fujian Tribune (The Humanities \& Social Sciences Bimonthly) ,12(2015)192-198.

[10] Miao Jie. New Thoughts and New Measures of Farmers' Rights and Interests Guarantee in the Process of Land Transfer. Academic Journal of Zhongzhou, 8(2015)45-49. 